\title{
Criteria of radiological diagnosis for neonates with hypochondroplasia
}

\author{
Keisuke Nagasaki ${ }^{1 *}$, Tomoko Saito ${ }^{1}$, Masaki Takagi ${ }^{2,3}$, Tomonobu Hasegawa $^{3}$, Gen Nishimura ${ }^{2}$ \\ From 8th APPES Biennial Scientific Meeting \\ Darwin, Australia. 29 October - 1 November 2014
}

\section{Introduction}

The diagnosis of hypochondroplasia $(\mathrm{HCH})$ is hampered by absence of radiological criteria relevant to the agedependent manifestations, particularly those in the neonatal period. This work deals with the radiological features in hypochondroplastic neonates with a FGFR3 mutation, including quantitative measurement that facilitates the definitive diagnosis. We propose the radiological criteria for $\mathrm{HCH}$ in the neonatal period.

\section{Patients and methods}

Subjects included six $\mathrm{HCH}$ neonates with FGFR3 mutations and 30 control subjects, in whom radiological examination was available as a neonate. The following findings were evaluated: 1) short ilia, 2) squared ilia, 3) short greater sciatic notch, 4) horizontal acetabula, 5) short femora, 6) stubby femora, 7) metaphyseal flaring, 8) lumboscaral interpediculate distance narrowing, and 9) oval radiolucency in the proximal femora.

\section{Results}

All measurement parameters for short ilia, short greater sciatic notch, horizontal acetabula, short femora and stubby femora (parameters $1,3,4,5$, and 6) were statistically different between $\mathrm{HCH}$ and control, while the other parameters 2, 7, and 8 were not. Based on these results, we tentatively made the criteria and scoring system for the diagnosis of $\mathrm{HCH}$. The major criteria that are given a score of 2 comprise parameters 1,3 , and 6 , whose distribution was not overlapped between $\mathrm{HCH}$ and control. The minor criteria that are given a score of 1 point comprise parameters 4 and 5 , and 9 , because the parameter 4 was overlapped in distribution between $\mathrm{HCH}$ and control, the parameter 5 is a non-specific

${ }^{1}$ Niigata University Graduate School of Medicine and Dental Sciences, Niigata, Japan

Full list of author information is available at the end of the article finding, and the parameter 9 is subjective in assessment. We presumed that a total score of 6 points or higher warrant a diagnosis of $\mathrm{HCH}$.

\section{Conclusion}

$\mathrm{HCH}$ was clearly distinguishable from normal infants assessing the skeletal findings of the ilia and proximal femora on neonatal roentgenograms. We compiled a set of diagnostic criteria for the early diagnosis of hypochondroplastic neonates.

\section{Authors' details}

${ }^{1}$ Niigata University Graduate School of Medicine and Dental Sciences, Niigata, Japan. ${ }^{2} T o k y o$ Metropolitan Children's Medical Center, Tokyo, Japan. ${ }^{3}$ Keio University School of Medicine, Tokyo, Japan.

Published: 28 April 2015

doi:10.1186/1687-9856-2015-S1-O24

Cite this article as: Nagasaki et al:: Criteria of radiological diagnosis for neonates with hypochondroplasia. International Journal of Pediatric Endocrinology 2015 2015(Suppl 1):O24.

Submit your next manuscript to BioMed Central and take full advantage of:

- Convenient online submission

- Thorough peer review

- No space constraints or color figure charges

- Immediate publication on acceptance

- Inclusion in PubMed, CAS, Scopus and Google Scholar

- Research which is freely available for redistribution 